\title{
Prognostic Value of Interleukin-17 A Gene Polymorphism and Serum IL-17 Levels in Adult Acute Myeloid Leukaemia Patients
}

Ahmed A Alnagar', Mohamed H Mourad ${ }^{2}$, Zainab A Farrag ${ }^{2}$, Lamiaa M Kamel ${ }^{2}$

Departments of ${ }^{1}$ Medical Oncology and ${ }^{2}$ Clinical Pathology , Faculty of Medicine, Zagazig University, Egypt

*Corresponding author: Zainab A Farrag, Mobile:(+20), Email: drzainabfarrag@gmail.com

\begin{abstract}
Background: T helper 17 (Th17) cells play a role in the pathogenesis and prognosis of acute myeloid leukemia (AML). Th17 cells produce interleukin (IL)-17A and IL-17F, that share strong surface expression and homology of the IL-23 receptor (IL-23R).

Objective: To evaluate the expression of IL-17A gene polymorphism and IL-17 serum level in adult AML patients and to clarify its prognostic significance.

Patients and methods: In this prospective study, 48 patients with de novo AML and 48 healthy matched controls were enrolled. Cases were diagnosed at clinical pathology and managed in Medical Oncology Departments. We evaluated both serum IL-17 levels, measured by ELISA, and IL-17A (rs2275913) gene polymorphism was assessed using realtime polymerase chain reaction (PCR) in all patients and control. All patients received " $3+7$ " as induction, responders received 3-4 courses of high dose cytarabine as consolidation, while non-responders received salvage therapy.

Results: Serum levels of IL-17 were higher in AML patients (median $27 \mathrm{pg} / \mathrm{ml}$ ) vs $17 \mathrm{pg} / \mathrm{ml}$ in the control group $(\mathrm{P}<$ 0.001). Also, serum IL 17 level was higher in non-responders with median $37.5(\mathrm{pg} / \mathrm{ml})$ vs $23(\mathrm{pg} / \mathrm{ml})$ in responders ( $\mathrm{P}<0.001)$. while IL-17A mutant genotypes and alleles showed no significant relation between expression of IL-17 A gene polymorphism and response to treatment or outcome of studied AML cases.

Conclusion: Serum IL-17 levels can be considered a useful diagnostic and prognostic factor in AML patients, unlike IL-17 A gene polymorphisms.
\end{abstract}

Keywords: IL-17, Prognostic, Polymorphisms, AML.

\section{INTRODUCTION}

Acute myeloid leukaemia (AML) is an aggressive haematological malignancy resulting from the clonal expansion of abnormal myeloid progenitors ${ }^{(\mathbf{1})}$.

$\mathrm{T}$ helper lymphocytes produce pro-inflammatory interleukin-17 (IL-17) that plays a critical role in many types of cancers and inflammatory diseases (2). IL-17 triggers proliferation of IL-17R (IL-17 receptor)-positive AML cells by activating the PI3K/Akt and Jak/Stat3 signaling pathways. IL-17 increases in the bone marrow and blood in AML patients more than in healthy controls (3). IL-17 can activate MAPK, PI3K/Akt, NF- $\kappa B$, and STAT3 downstream signaling pathways to regulate AML progression (4). IL-17A (rs2275913) polymorphisms might be responsible for chronic inflammatory diseases, autoimmune diseases and malignancies as an inducer of inflammatory chemokines secretion also release cytokines stored in neutrophils and macrophages ${ }^{(5)}$.

We aimed to evaluate the expression of IL-17A gene polymorphism and IL-17 serum level in adult AML patients and to clarify its prognostic significance.

\section{PATIENTS AND METHODS}

This prospective study was conducted in the Clinical Pathology and Medical Oncology Departments, over two years from December 2015 to December 2017. We assessed serum IL-17 levels and the expression of IL17A in 48 de novo adult AML patients and 48 age and sex-matched controls. We studied the relationship between IL-17A gene polymorphisms, serum IL-17 levels and the prognosis and response to therapy. We enrolled in our study, De novo AML patients aged 18 to 60 years, with an ECOG performance status of two or less. Liver and kidney function tests were within the normal range. Normal cardiac functions tests. Patients with relapsed or secondary AML, promyelocytic leukaemia, prior history of exposure to radiation, or chemotherapy, patients with other malignancies, history of myelodysplastic or myeloproliferative neoplasm, patients with impaired renal, cardiac and liver function or patient refusal were excluded.

\section{Ethical approval:}

The Institutional Review Board (IRB) approved this study (IRB) (2465-15-12-2015) chaired by the Faculty of Medicine. Informed consent was obtained from all subjects.

\section{Methods of IL-17 detection: \\ Detection of Interleukin-17 A gene polymorphism rs 2275913 by Real-Time PCR technique}

For DNA extraction, $2 \mathrm{ml}$ samples of blood were collected into a sterile tube containing EDTA. The samples were stored in the same vacutainer at $-20^{\circ} \mathrm{C}$ before processing. The GeneJET Genomic DNA Purification Kit (California, USA) was used for DNA isolation. Then DNA concentration was measured for adjustment of the needed sample volume used in PCR 
reaction (20 ng). $20 \mu 1$ of each extracted DNA sample were applied to Nanodrop 2000 (Thermo Scientific, USA ) spectrophotometer.

The allelic discrimination of the IL-17 A polymorphism rs 2275913 gene intron polymorphism was assessed with the QuantstudioTM 3 system (RealTime PCR System) (Applied Biosystems, Thermos Fisher Scientific, Singapore) and analyzed (using analysis software v1.4.3, applied biosystems), using the TaqMan assay (assay IDs: C-15879983-10). The reaction mixture included ,TaqMan universal PCR master Mix $(10 \mu \mathrm{l})$,working stock of SNP genotyping assay $(1 \mu \mathrm{l})$, DNase free water $(7 \mu \mathrm{l})$ and DNA template $(2 \mu \mathrm{l})$ with total volume $20 \mu \mathrm{l} / \mathrm{well}$, then mixed thoroughly and dispensed in appropriate wells of PCR plate.

Amplification reaction was performed according to the following thermal condition, polymerase activation hold at $95^{\circ} \mathrm{C}$ for 10 minutes then 50 cycles including both denaturation at $95^{\circ} \mathrm{C}$ for 15 second and Anneal/extension at $60^{\circ} \mathrm{C}$ for 90 second .

Allelic discrimination plot discriminated type of IL-17A gene rs2275913 SNP AA, AG or GG according to the detected dye VIC or FAM. $\mathbf{G}$ is the wild allele, $\mathbf{A}$ is the mutant allele and GG is the wild genotype. Homozygous AA and Heterozygous AG are the high risk (mutant) genotypes.

\section{Serum IL-17 assay by Enzyme-linked immunosorbent assay (ELISA):}

The assay was carried out by Interleukin-17 doubleantibody sandwich ELISA kit provided by Bio Company (Shanghai). A double-antibody sandwich enzyme-linked immunosorbent assay (ELISA) to assay the level of human interleukin-17(IL-17) in samples. Interleukin-17 was added to monoclonal antibody enzyme well, which is pre-coated with human interleukin-17 monoclonal antibody.

Assessment:
We analyzed demographics, clinical and laboratory data (CBC with a blood film, liver and kidney function tests, coagulation profile, electrolytes level, virology (HCV Ab, HBs Ag, HBc Ab, HIV Ab) and CSF cytology as indicated. Specific investigations such as immunophenotyping, BMA karyotyping by $\mathrm{G}$ banding technique, serum interleukin-17 levels, the molecular detection of interleukin-17A gene polymorphism rs 2275913 by Real-Time PCR technique were also undertaken.

\section{Treatment:}

Patients in the intervention arm were treated with the standard " $3+7$ " protocol (doxorubicin $25 \mathrm{mg} / \mathrm{m}^{2}$ iv per day for three days plus cytarabine $100 \mathrm{mg} / \mathrm{m}^{2}$ continuous IV infusion day 1-7). Bone marrow evaluations were done on days 14 and 28. Patients who achieved CR went on to receive three to four cycles of consolidation with high-dose cytosine arabinoside, with doses modified when necessary.

\section{Statistical analysis}

Data were collected retrospectively from patients' medical files, and analysis was done using the SPSS statistics software (Version 22, IBM Corp., Armonk, NY). We used binary logistic regression to compare between genotypes of both groups. Unpaired student ttest was used to compare quantitative variables. MannWhitney $\mathrm{U}$ test was used to analyze ELISA data. The corresponding P-value: Non-significant (NS) difference if $\mathrm{P}>0.05$, Significant(S) if $\mathrm{P}$-value $\leq 0.05$.

\section{RESULTS}

Age and sex distribution were not significantly different between the two groups with median age 46 years in cases group compared to 48.5 years in the control group (with $\mathrm{P}$ value 0.829 ). 58.3\% of patients were males in cases group compared to $54.2 \%$ in the control group (with $\mathrm{P}$ value 0.68 ) as shown in table (1). 
Table (1): Demographic, clinical and laboratory data among the studied cases.

\begin{tabular}{|c|c|}
\hline Variables & \multirow{2}{*}{$\begin{array}{l}\text { Cases }=\mathbf{4 8} \\
46 \quad(18-60)\end{array}$} \\
\hline Median (range) & \\
\hline Sex : & \\
\hline Male & $28(58.3 \%)$ \\
\hline Female & $20(41.7 \%)$ \\
\hline Hemoglobin (gm|dl) $\quad$ Median (Range) & $8.5(4.8-13.9)$ \\
\hline $\begin{array}{ll}\text { Platelets }\left(\mathbf{x 1 0}^{3} / \mathbf{c c}\right) & \text { Median (Range) }\end{array}$ & $31.5(6-176)$ \\
\hline TLC $\left.(\mathbf{x 1 0})^{3} / \mathbf{c c}\right) \quad$ Median (Range) & $51.5(1.5-361.1)$ \\
\hline ESR (cm) $\quad$ Median (Range) & $80.5(20-125)$ \\
\hline $\begin{array}{ll}\text { LDH (units/L) } & \text { Median (Range) }\end{array}$ & $614(138-1590)$ \\
\hline $\begin{array}{ll}\text { PB blast } & \text { Median (Range) }\end{array}$ & $55(2-94)$ \\
\hline BM blast $\quad$ Median (Range) & $72.5(28-98)$ \\
\hline Total bilirubin (mg/dl) Median (Range) & $0.6(0.3-1.1)$ \\
\hline Direct bilirubin (mg/dl) Median (Range) & $0.2(0.1-0.6)$ \\
\hline $\begin{array}{ll}\text { Albumin (g/dl) } & \text { Median (Range) }\end{array}$ & $3.4(2.4-5.1)$ \\
\hline AST(IU/L) $\quad$ Median (Range) & $21.5(7-65)$ \\
\hline ALT(IU/L) $\quad$ Median (Range) & $22(8-79)$ \\
\hline PTT (sec) $\quad$ Median (Range) & $33.1(25.5-51)$ \\
\hline PT (sec) $\quad$ Median (Range) & $12.9(11.5-29.8)$ \\
\hline Creatinine (mg/dl) $\quad$ Median (Range) & $0.8(0.4-2)$ \\
\hline $\begin{array}{ll}\text { BUN (mgldl) } & \text { Median Range) }\end{array}$ & $12.7(3.2-35)$ \\
\hline Splenomegally $\quad$ No (\%) & $10(20.8 \%)$ \\
\hline Lymphadenopathy & $4(8.3 \%)$ \\
\hline Purpera & $39(81.2 \%)$ \\
\hline Fatigue & $43(89.6 \%)$ \\
\hline Gum bleeding & $21(43.8 \%)$ \\
\hline Fever & $40(83.3 \%)$ \\
\hline $\begin{array}{ll}\text { With myeloid differentiation } & \text { No (\%) }\end{array}$ & $19(39.6 \%)$ \\
\hline & $5(10.4 \%)$ \\
\hline M1 & $4(8.3 \%)$ \\
\hline M2 & $10(20.8 \%)$ \\
\hline With monocytic differentiation & $29(60.4 \%)$ \\
\hline M4 & $13(27.1 \%)$ \\
\hline M5a & $12(25 \%)$ \\
\hline M5b & $4(8.3 \%)$ \\
\hline Risk Favorable & $4(8.3 \%)$ \\
\hline $\mathrm{t}(8 ; 21)$ & $2(4.15 \%)$ \\
\hline Inv 16 & $2(4.15 \%)$ \\
\hline Intermediate & $42(87.5 \%)$ \\
\hline Normal & $40(83.3 \%)$ \\
\hline$+1,3,10$ & $1(2.1 \%)$ \\
\hline del y & $1(2.1 \%)$ \\
\hline Adverse & $2(4.2 \%)$ \\
\hline Monosomy 7 & $1(2.1 \%)$ \\
\hline $\operatorname{Inv}(3)$ & $1(2.1 \%)$ \\
\hline CR (mg/dL) & $26(54.2 \%)$ \\
\hline NR & $22(45.8 \%)$ \\
\hline $\mathbf{C R}$ & \\
\hline - Alive & $\begin{array}{c}(\mathrm{n}=26) \\
21(808 \%)\end{array}$ \\
\hline - Relapse & $\begin{array}{c}21(80.8 \%) \\
4(15.4 \%)\end{array}$ \\
\hline - Relapse and died & $1(3.8 \%)$ \\
\hline NR & $\begin{array}{l}(\mathrm{n}=22) \\
1(45 \%)\end{array}$ \\
\hline - Alive & $\begin{array}{c}1(4.5 \%) \\
21(95.5 \%)\end{array}$ \\
\hline - Died & \\
\hline
\end{tabular}

S: Significant p-value $<0.05$, NS: not significant p-value $>0.05^{*}$ Mann-whitney test of non-parametric data

IL-17 gene genotypes and allele distribution did not differ between AML cases and control group. However, risk of having disease was increased in AG variant carriers (OR: 3.4; 95\%CI: 1.1-6.3) as shown in table (2). 
Table (2): Different genotypes and allele distribution of IL-17 gene among both studied AML cases and controls.

\begin{tabular}{|c|c|c|c|c|c|c|c|}
\hline \multirow[t]{3}{*}{ Genotype } & \multicolumn{4}{|c|}{ Group } & \multirow{3}{*}{$\mathbf{X}^{2}$} & \multirow{3}{*}{ P-value } & \multirow{3}{*}{ OR (95\% CI) } \\
\hline & \multicolumn{2}{|c|}{ AML $(n=48)$} & \multicolumn{2}{|c|}{ Controls $(n=48)$} & & & \\
\hline & $\mathbf{N}$ & $\%$ & $\mathbf{N}$ & $\%$ & & & \\
\hline \multirow{3}{*}{$\begin{array}{l}\text { Homozygous AA } \\
\text { Heterozygous AG } \\
\text { Wild GG }\end{array}$} & 15 & 31.2 & 17 & 35.4 & --- & ---- & 1 \\
\hline & 20 & 41.7 & 12 & 25 & 3.1 & $0.08(\mathrm{NS})$ & $3.4(1.1-6.3)$ \\
\hline & 13 & 27.1 & 19 & 39.5 & 1.7 & 0.193 (NS) & $0.45(0.23-0.63)$ \\
\hline \multirow{2}{*}{$\begin{array}{l}\text { A allele } \\
\mathrm{G} \text { allele }\end{array}$} & 50 & 52.1 & 46 & 47.9 & \multirow[t]{2}{*}{0.33} & \multirow[t]{2}{*}{$0.56 \mathrm{NS}$} & \multirow[t]{2}{*}{$1.52(0.75-3.64)$} \\
\hline & 46 & 47.9 & 50 & 52.1 & & & \\
\hline
\end{tabular}

P-value $>0.05$ (Not significant)

$*$ P-value $<0.05$ (significant)

There was no statistically significant relation between IL-17 gene polymorphism and FAB classification, cytogenetic prognosis, response to treatment or outcome of studied AML cases (Table 3).

Table (3): Relation between IL-17 gene polymorphism and FAB classification, cytogenetic risk categories and response to treatment among studied AML cases.

\begin{tabular}{|c|c|c|c|c|c|c|c|c|}
\hline \multirow{2}{*}{ Variables } & \multicolumn{6}{|c|}{ Risk categories } & \multirow{2}{*}{$\begin{array}{c}\mathbf{X}^{2} \\
\text { Test }\end{array}$} & \multirow{2}{*}{ P-value } \\
\hline & & & & & & & & \\
\hline $\begin{array}{l}\text { FAB } \\
\text { Myeloid differentiation } \\
\text { M 0 } \\
\text { M1 } \\
\text { M2 } \\
\text { Monocytic differentiation } \\
\text { M4 } \\
\text { M5a } \\
\text { M5b } \\
\end{array}$ & $\begin{array}{l}\mathbf{N} \\
6 \\
3 \\
\mathbf{0} \\
3 \\
9 \\
4 \\
4 \\
\mathbf{1} \\
\end{array}$ & $\begin{array}{c}\% \\
40 \\
20 \\
0.0 \\
20 \\
60 \\
26.7 \\
26.7 \\
6.7 \\
\end{array}$ & \begin{tabular}{|c|}
$\mathbf{N}$ \\
7 \\
1 \\
3 \\
3 \\
13 \\
7 \\
5 \\
1 \\
\end{tabular} & $\begin{array}{c}\% \\
35 \\
5 \\
15 \\
15 \\
65 \\
35 \\
25 \\
5 \\
\end{array}$ & $\begin{array}{l}\mathbf{N} \\
6 \\
1 \\
1 \\
4 \\
7 \\
2 \\
3 \\
2 \\
\end{array}$ & \begin{tabular}{c|}
$\%$ \\
46.2 \\
7.7 \\
7.7 \\
30.8 \\
53.8 \\
15.4 \\
23.1 \\
15.4 \\
\end{tabular} & \begin{tabular}{c|}
0.41 \\
2.2 \\
0.78 \\
1.2 \\
\\
\\
1.5 \\
0.05 \\
1.2 \\
\end{tabular} & $\begin{array}{c}0.814 \text { (NS) } \\
0.331 \text { (NS) } \\
0.677 \text { (NS) } \\
0.55 \text { (NS) } \\
\\
0.46 \text { (NS) } \\
0.98 \text { (NS) } \\
0.551 \text { (NS) } \\
\end{array}$ \\
\hline $\begin{array}{l}\text { Risk } \\
\text { Favourable } \\
\mathrm{t}(8 ; 21) \\
\text { Inv 16 } \\
\text { Intermediate } \\
\text { Normal } \\
\text { Tri,1,3,10 } \\
\text { Del y } \\
\text { Adverse } \\
\text { Monosomy } 7 \\
\text { Tri ,1,3 } \\
\end{array}$ & $\begin{array}{c}1 \\
1 \\
0 \\
13 \\
13 \\
0 \\
0 \\
1 \\
1 \\
0\end{array}$ & $\begin{array}{c}6.7 \\
6.7 \\
0.0 \\
86.6 \\
86.6 \\
0.0 \\
0.0 \\
6.7 \\
6.7 \\
0.0\end{array}$ & $\begin{array}{l}2 \\
1 \\
1 \\
17 \\
16 \\
1 \\
0 \\
1 \\
0 \\
1\end{array}$ & $\begin{array}{c}10 \\
5 \\
5 \\
85 \\
80 \\
5 \\
0.0 \\
5 \\
0.0 \\
5\end{array}$ & $\begin{array}{c}1 \\
0 \\
1 \\
12 \\
11 \\
0 \\
1 \\
0 \\
0 \\
0\end{array}$ & $\begin{array}{c}7.7 \\
0.0 \\
7.7 \\
92.3 \\
84.6 \\
0.0 \\
7.7 \\
0.0 \\
0.0 \\
0.0\end{array}$ & $\begin{array}{c}0.13 \\
0.522 \\
0.634 \\
0.399 \\
0.432 \\
1.02 \\
1.23 \\
1.2 \\
0.984 \\
0.865\end{array}$ & $\begin{array}{c}0.94 \\
0.399 \\
0.231 \\
0.211 \\
0.321 \\
0.09 \\
0.08 \\
0.08 \\
0.321 \\
0.423\end{array}$ \\
\hline $\begin{array}{l}\text { Response } \\
\text { CR } \\
\text { NR }\end{array}$ & $\begin{array}{l}7 \\
8\end{array}$ & $\begin{array}{l}46.7 \\
53.3\end{array}$ & $\begin{array}{c}11 \\
9\end{array}$ & $\begin{array}{l}55 \\
45\end{array}$ & $\begin{array}{l}8 \\
5\end{array}$ & $\begin{array}{l}61.5 \\
38.5\end{array}$ & 0.63 & $\begin{array}{c}0.73 \\
\text { NS }\end{array}$ \\
\hline $\begin{array}{l}\text { Follow up } 2 \text { years } \\
\text { Alive } \\
\text { Relapse } \\
\text { Relapse \& died } \\
\text { Died }\end{array}$ & $\begin{array}{l}5 \\
3 \\
0 \\
7\end{array}$ & $\begin{array}{c}33.3 \\
20 \\
0.0 \\
46.7\end{array}$ & $\begin{array}{l}9 \\
1 \\
1 \\
9\end{array}$ & $\begin{array}{c}45 \\
5 \\
5 \\
45\end{array}$ & $\begin{array}{l}8 \\
0 \\
0 \\
5\end{array}$ & $\begin{array}{c}61.5 \\
0.0 \\
0.0 \\
38.5\end{array}$ & $\begin{array}{c}2.24 \\
2.53 \\
0.865 \\
0.212\end{array}$ & $\begin{array}{c}0.33 \\
0.09 \\
0.423 \\
0.899\end{array}$ \\
\hline
\end{tabular}

P-value $>0.05$ (Not significant)

$*$ P-value $<0.05$ (significant)

Table (4) showed that there was astatically significant difference between cases and controls as levels of IL17 was higher among different genotypes of cases than controls .Also, in patients the level of serum IL 17was higher in AG genotype than other genotypes but this increase was not statistically significant.

Regarding the relation between the level of serum IL-17 and treatment response in AML cases, our results showed that IL-17 serum level was statistically significantly higher among studied cases with no remission (22 patients) with median 37.5 (pg/ml) versus those showed complete remission (26 patients), with a median of $23(\mathrm{pg} / \mathrm{ml})$ with P-value $<0.001$.

Concerning validity of data of IL-17 serum level as a diagnostic marker in AML cases, we found that at cut off point >20.5, IL-17 can differentiate between the studied AML patients and control with area under the curve $=0.66$, having a sensitivity of $79.2 \%$ and 
specificity of $72.9 \%$ with PPV $74.5 \%$, NPV $77.8 \%$ and accuracy $76 \%$. While the optimal cut off value of serum IL-17 as a prognostic marker is $\geq 25.5 \mathrm{pg} / \mathrm{ml}$ to detect no remission for AML patients with sensitivity of $95.5 \%$ and specificity of $73.1 \%$ with PPV $75 \%$, NPV $95 \%$ and accuracy $83.3 \%$. Serum IL17 is an excellent prognostic test $(\mathrm{AUC}=0.95)$ to differentiate between treatment response (complete remission or no remission) for AML patients.

Table (4): Relation between serum IL-17 and gene polymorphism among studied AML cases and control group.

\begin{tabular}{|c|c|c|c|c|c|c|}
\hline Variables & Total & \multicolumn{3}{|c|}{ Risk categories } & \multirow[b]{2}{*}{$\begin{array}{l}\text { KW } \\
\text { test }\end{array}$} & \multirow[b]{2}{*}{ P-value } \\
\hline AML cases & & $\underset{\mathrm{N}=15}{\mathrm{AA}}$ & $\begin{array}{c}\mathbf{A G} \\
\mathbf{N}=20\end{array}$ & $\begin{array}{c}\text { GG } \\
\mathrm{N}=13\end{array}$ & & \\
\hline $\begin{array}{l}\text { Serum IL-17 (pg\ml) } \\
\text { Median } \\
\text { Mean } \pm \text { SD } \\
\end{array}$ & $\begin{array}{c}27 \\
46.5 \pm 5 \\
\end{array}$ & $\begin{array}{c}11 \\
44.2 \pm 5.7 \\
\end{array}$ & $\begin{array}{c}21 \\
51.2 \pm 63.4\end{array}$ & $\begin{array}{c}13 \\
40.2 \pm 9.8 \\
\end{array}$ & 0.17 & $\begin{array}{l}0.919 \\
\mathrm{NS} \\
\end{array}$ \\
\hline Control group & & $\begin{array}{c}\mathbf{A A} \\
\mathbf{N}=17\end{array}$ & $\begin{array}{c}\mathrm{AG} \\
\mathrm{N}=12\end{array}$ & $\begin{array}{c}\text { GG } \\
N=19\end{array}$ & & \\
\hline $\begin{array}{l}\text { Serum IL-17 }(\text { pg } \backslash \mathrm{ml}) \\
\text { Median } \\
\text { Mean } \pm \text { SD }\end{array}$ & $\begin{array}{c}17 \\
15.9 \pm 3.1 \\
\end{array}$ & $\begin{array}{c}14 \\
14.4 \pm 3.3 \\
\end{array}$ & $\begin{array}{c}12.5 \\
15.4 \pm 3.3 \\
\end{array}$ & $\begin{array}{c}18 \\
17.3 \pm 3.3 \\
\end{array}$ & 1.2 & $\begin{array}{l}0.549 \\
\text { NS }\end{array}$ \\
\hline $\begin{array}{l}\text { P-value between each } \\
\text { genotype }\end{array}$ & $\begin{array}{c}<0.001 \\
\mathrm{~S}\end{array}$ & $\begin{array}{l}0.001 \\
S\end{array}$ & $\begin{array}{l}0.006 \\
S\end{array}$ & $\begin{array}{l}\mathbf{0 . 0 0 7} \\
(\mathbf{S})\end{array}$ & & \\
\hline
\end{tabular}

Table (5) showed that regarding two years survival, the three IL-17A gene polymorphism did not differ significantly with p-value (0.371) (figure 1).

Table (5): Two years survival analysis of studied AML cases according to IL 17A gene polymorphism.

\begin{tabular}{|c|c|c|c|c|c|c|}
\hline \multirow[b]{2}{*}{$\begin{array}{l}\text { IL 17A gene } \\
\text { polymorphism }\end{array}$} & \multirow[b]{2}{*}{$\begin{array}{l}\text { Mean survival } \\
\text { (months) }\end{array}$} & \multirow{2}{*}{$\begin{array}{l}\text { Total number of } \\
\text { patients }\end{array}$} & \multirow[b]{2}{*}{$\begin{array}{l}\text { deaths } \\
\text { No(\%) }\end{array}$} & \multicolumn{2}{|c|}{ Survival } & \multirow{2}{*}{$\mathrm{p}$} \\
\hline & & & & $\mathrm{N}$ & Percent & \\
\hline $\mathrm{G} / \mathrm{G}$ & 17 & 13 & $5(38.5 \%)$ & 8 & $61.5 \%$ & \\
\hline $\mathrm{A} / \mathrm{G}$ & 13.3 & 20 & $12(60 \%)$ & 8 & $40.0 \%$ & 0.371 \\
\hline A/A & 17.12 & 15 & $6(40 \%)$ & 9 & $60.0 \%$ & \\
\hline
\end{tabular}

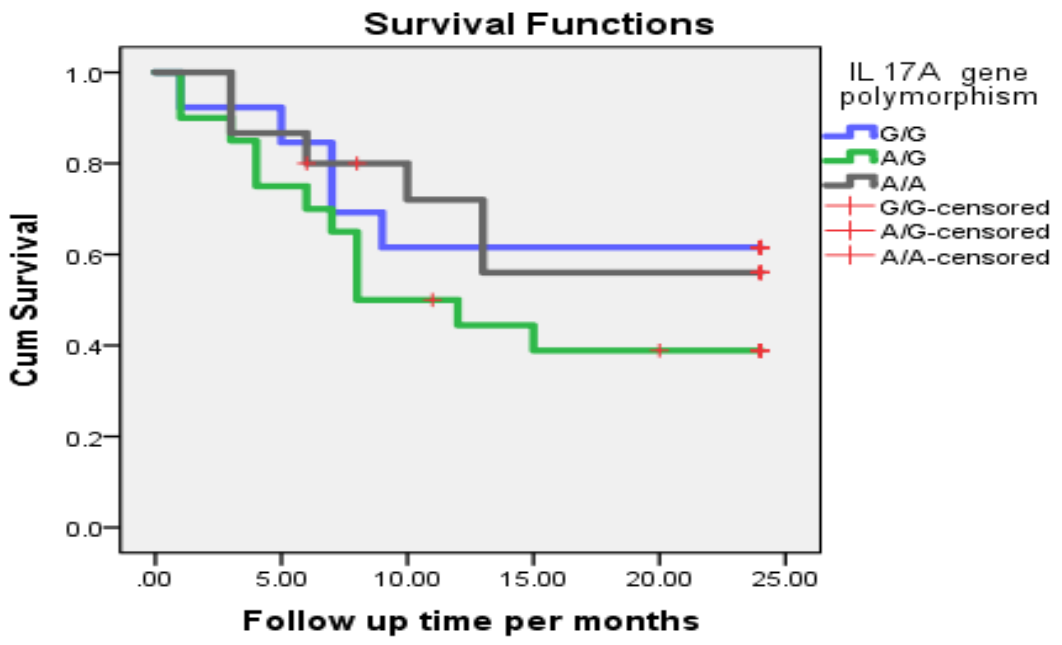

Figure (1): Kaplan-Meier survival analysis two years of studied AML cases according to IL-17A gene polymorphism $(n=48)$.

Overall survival of studied AML cases (48 cases) at two years of follow-up was $52.1 \%$ with a mean time of 15.52 month, while the two years event-free survival of the responding cases (26 cases) was $80.8 \%$ with a mean time of 21.65 months. As regards two years event-free survival analysis of studied AML cases according to IL-17A gene polymorphism $(n=26)$, we found that leukaemia event-free survival for $\mathrm{G} / \mathrm{G}$ genotype 8 patients was $100 \%$, A/G genotype 9 patients was $66.7 \%$ and A/A genotype 9 patients was $77.8 \%$ during 24 months follow up, with p-value 0.26 (no significant difference). 


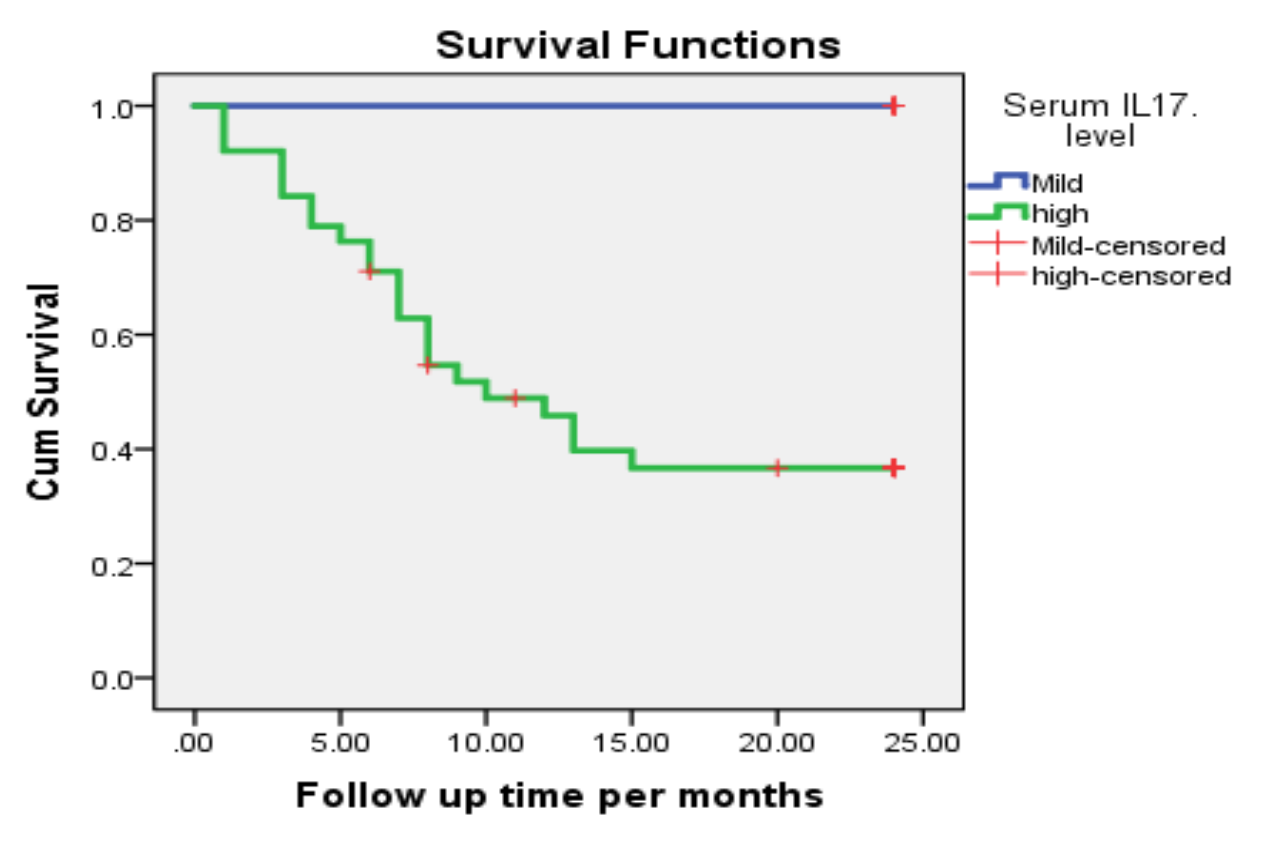

Figure (2): Kaplan-Meier survival analysis two years of studied AML cases according to Serum IL17 level (n=48). Two years survival for patients with high serum IL-17 leukaemia patients was $25 \%$ compared to 95\% among patients with serum IL-17 < 25.5 that was a statistically significant difference with p-value 0.0001 (Table 6). 22 patient died 22/48 (45.8\%); 21 patients of non-responder with one patient in responders who relapsed and died during receiving salvage therapy. 8 (16.7\%) patients died during the induction period (induction death), during consolidation one patient (2.1\%) died as a result of chemotherapy toxicity, $13(27.2 \%)$ patients died from the toxicity of salvage chemotherapy. In patients not achieving remission, cause of death was mainly due to disease, while deaths during induction and in relapsed patients were mainly due to toxicity of chemotherapy (Table 6 and Fig 2).

Nearly all patients developed variable degrees of haematological toxicities mostly grade 4 while sepsis during induction was more common than in consolidation.

Table (6): Two years survival analysis of studied AML cases according to serum IL-17 level $(\mathrm{n}=48)$.

\begin{tabular}{|c|c|c|c|c|c|c|}
\hline $\begin{array}{c}\text { Serum IL17 } \\
\text { level }\end{array}$ & Estimated Mean of & Total number & Deaths & \multicolumn{2}{|c|}{ Survival } & $\mathrm{p}$ \\
\cline { 5 - 8 } & of patients & $\mathrm{N}(\%)$ & $\mathrm{N}$ & Percent & \\
\hline$\geq 25.5 \mathrm{pg} / \mathrm{ml}$ & 10.9 & 28 & $21(75 \%)$ & 7 & $25 \%$ & 0.0001 \\
\hline$<25.5 \mathrm{pg} / \mathrm{ml}$ & 22.85 & 20 & $1(5 \%)$ & 19 & $95 \%$ & \\
\hline
\end{tabular}

P-value $>0.05$ (Not significant)

* $\mathrm{P}$-value $<0.05$ (significant)

\section{DISCUSSION}

AML is a complex hematopoietic neoplasm. Epigenetic modifications cause abnormal proliferation and de-differentiation of myeloid hematopoietic cells ${ }^{\left({ }^{(6)}\right.}$. The leukaemia cells in AML cases are highly proinflammatory compared to normal hematopoietic counterparts ${ }^{(7,8)}$. IL-17 family are a group of proinflammatory cytokines that have a pivotal role in various types of cancers and inflammatory diseases ${ }^{(2,9)}$.

In our study, IL-17A gene polymorphic genotypes expression in AML cases was assessed, as well as serum IL-17. We found that serum $\mathrm{IL}-17$ was statistically significantly higher $(\mathrm{p}<0.001)$ in AML cases than the controls. This agrees with Han et al. (3), Nasreldin et al. ${ }^{\left({ }^{(1)}\right)}$ and Mahfouz et al. ${ }^{(11)}$ who concluded that in denovo AML patients IL-17 levels were significantly higher than the control group. Serum IL-17 level was statistically significantly higher among studied cases with no remission than those showed complete remission with mean of $77.3 \pm 69.7$ versus $20.5 \pm 8.32$. Also, this agrees with Nasreldin et al. ${ }^{(\mathbf{1 0})}$ who reported lower levels in patients achieved complete remission following chemotherapy. These findings agree with the hypothesis that IL-17 serum level is associated with AML pathogenesis and can be used as a predictor for treatment response. Abousamra et al. ${ }^{(12)}$ found that serum IL-17 level was significantly higher in acute leukaemia patients. Pretreatment Th17 cells decreased significantly in patients receiving induction therapy and achieving complete remission $(\mathrm{P}<0.0001)$. This is consistent with our findings. Th17 cells is a powerful new prognostic marker which could serve as a new therapeutic target.

In contrary, Wrobel et al. ${ }^{(13)}$ and Elsissy et al. ${ }^{(14)}$ found that the serum IL-17 level was not elevated in AML patients and did not vary between AML patients and healthy subjects. They concluded that no significant relationship between IL-17 levels and AML incidence. Moreover, case-control studies by Elsissy $\boldsymbol{e t}$ al. ${ }^{(14)}$ and Zhu et al. ${ }^{(15)}$ found no significant relationship between 
serum IL-17 level and disease progression or response and no difference between AML patients and healthy controls.

Regarding the validity of IL-17 serum level as a diagnostic marker of AML cases, our study found that the cut-off level of IL-17 among the studied AML patients was $>20.5 \mathrm{pg} / \mathrm{mL}$. The area under curve $=0.66$ that had a sensitivity of $79.2 \%$, a specificity of $72.9 \%$, PVP of $74.5 \%$, PVN of $77.8 \%$ and accuracy of $76 \%$. Conversely, Mahfouz et al. ${ }^{(11)}$ showed a lower diagnostic level of IL17. They reported that the best cut-off point was $\geq 9.3$ $\mathrm{pg} / \mathrm{mL}$ with sensitivity and specificity $(85.2 \%$ \& $74.5 \%$ respectively). Positive and negative predictive values were $62.2 \%$ \& $91.1 \%$ successively and accuracy was $78.0 \%$. The area under the curve was 0.87 .

Regarding validity of IL-17 serum level as a prognostic marker of AML cases, it was found that the prognostic level of $\mathrm{IL}-17$ for treatment response (Complete remission or no remission) for AML patients was $\geq 25.5 \mathrm{pg} / \mathrm{mL}$ with an area under the curve 0.93 , that have a sensitivity of $95.5 \%$ and specificity of $73.1 \%$. To our knowledge, this is the first study determining a cut off value for serum interleukin-17 as prognostic value in AML until now.

Regarding IL-17 gene polymorphism among studied participants, there was no significant difference among AML cases and control group regarding IL-17 gene genotypes or allele distribution. It was showed that there was no statistically significant relation between IL17 gene polymorphism and response to treatment or outcome of studied AML cases indicating that IL17 A gene polymorphism has no impact on AML. The current results agree with case-control studies by Elsissy et al. (14) at Egypt, and Ersvaer et al. (16) at Norway where they reported that there was no significant difference between the combined IL-17F [rs763780; A7488G] and IL-17A [rs2275913; G197A] polymorphism in AML patients and control group. Moreover, our results agree with Elsissy et al. ${ }^{(14)}$ and Zhu et al. ${ }^{(15)}$. They reported that no significant relationship in the distribution of IL17A gene polymprphism between patients achieving $\mathrm{CR}$ or not. Also, no significant difference of plasma level of IL-17 and with different IL-17 A gene polymorphism respectively. They found that IL-17 FG variant was observed more frequently in patients more than healthy.

We found that IL-17 gene AG heterozygous mutation carriers carry a higher risk of having disease. On the contrary, Mahfouz et al. ${ }^{(11)}$ concluded that IL-17F gene GG homozygous mutant and $\mathrm{G}$ single mutant were associated with susceptibility to AML in Egyptian population. In contrast, IL17-A and IL23-R polymorphisms were not associated with such susceptibility. Elsissy et al. ${ }^{(14)}$ and Zhu et $\boldsymbol{a l}$. $^{(15)}$ found that IL-17F G variant and its homozygosity were observed more frequently in patients more than in healthy individuals in Poland and China, respectively.

Variation in our results compared to other studies can be explained by the difference in patients ethnicity.
Also, plasma IL-17 values might be correlated with racial variations ${ }^{(15)}$.

Regarding the association between serum IL-17 and gene polymorphism, we demonstrated that there was no statistically significant relationship between them. This agrees with, Zhu $\boldsymbol{e t}$ al. ${ }^{(15)}$ who reported that there was no significant relationship observed with IL-17 plasma level and IL-17 gene polymorphism. Conversely, Mahfouz et al. ${ }^{(11)}$ found a statistically significant relation between IL-17 plasma level and the three genetic polymorphisms in studied groups.

In regard to relation of serum IL-17 and response, we found that IL-17 serum level was statistically significantly higher among cases with no remission than patients with complete remission (P-value $<0.001)$. In contrary to what was reported by Abousamra et al. (12) that pretreatment level of Th17 cells was higher in patients responding to induction therapy than non-responders, the difference may be because their study included both AML and ALL cases.

Two years survival for patients with high serum IL-17 leukaemia patients was $25 \%$ compared to $95 \%$ among patients with serum IL-17 $<25.5$. This showed a statistically significant difference with p-value $=0.0001$.

Regarding AML cases survival, it was revealed that the mean of two years OS was 15.52 months and the mean of EFS survival was 21.65 months. In Rashed $\boldsymbol{e t}$ al. (17) study, the median OS for AML patients was 6.12 months. Abousamra et al. ${ }^{(12)}$ demonstrated that serum IL-17 is a prognostic factor $(\mathrm{P}=0.035)$; this agrees with our results.

To our knowledge, our study is the first one evaluating the impact of IL-17 A gene polymorphism and serum IL-17 on survival analysis in AML patients. As regards two years survival analysis of studied AML cases according to IL-17A gene polymorphism, the mean time of survival for A/A genotype patients was 17.12 months, G/G phenotype patients were 17 months, and A/G phenotype patients was 13.3 months. This is meaning that the chance of survival is more for A/A. Nevertheless, there is no significant difference (p-value 0.371).

As a regards two years event-free survival analysis (EFS) of studied AML cases according to IL-17A gene polymorphism $(n=26)$, number of leukaemia eventfree survival for $\mathrm{G} / \mathrm{G}$ genotype patients was $100 \%$ during 24 months follow up, for A/G genotype patients were $66.7 \%$ during 24 months and for $\mathrm{A} / \mathrm{A}$ genotype patients was $77.8 \%$ during 24 months follow up with no significant difference $(\mathrm{p}$-value $=0.26)$.

\section{LIMITATION OF OUR STUDY}

Risk stratification based on only cytogenetics as other molecular markers as FLT3 is not available in our institute. We used Doxorubicin as it is the available anthracycline in our institute while BMT was not done in our institute.

\section{CONCLUSION}


By the end of this study, it was found that serum level of IL-17 is elevated among AML cases and associated with a decreased rate of complete remission and decreased survival. Therefore, elevated serum IL-17 level is a predictor of inadequate therapy response and survival. Further studies on a larger number of patients are needed for confirming our findings. Also, studies to evaluate IL-17 as a potential therapeutic target in AML.

\section{REFERENCE}

1. Guo H, Niu L, Qiang W et al. (2019): Leukemic IL-17RB signaling regulates leukemic survival and chemoresistance. The FASEB Journal, 33: 9565-95.

2. Fabre J, Giustiniani J, Garbar C et al. (2016): Targeting the Tumor Microenvironment: The Protumor Effects of IL17 Related to Cancer Type. International Journal of Molecular Sciences, 17 (9): 1433.

3. Han Y, Ye A, Bi L et al. (2014): Th17 cells and interleukin-17 increase with poor prognosis in patients with acute myeloid leukaemia. Cancer Sci., 105: 933-942.

4. Das S, Khader S (2017): Yin and yang of interleukin-17 in host immunity to infection. F1000 Res., 38: 311-322.

5. Kirkham B, Lassere M, Edmonds $J$ et al. (2006): Synovial membrane cytokine expression is predictive of joint damage progression in rheumatoid arthritis: a twoyear prospective study (the DAMAGE study cohort). Arthritis Rheum., 54: 1122-1131.

6. Thol F, Heuser M, Damm F et al. (2011): DNMT3A mutations are rare in childhood acute myeloid leukaemia. Haematologica., 96: 1238-1240.

7. Mirantes C, Passegue E, Pietras E (2014): Proinflammatory cytokines: emerging players regulating HSC function in normal and diseased hematopoiesis. Exp Cell Res., 329: 248-254.

8. Hemmati S, Haque T, Gritsman K (2017): Inflammatory signalling pathways in preleukemic and leukemic stem cells. Front Oncol., 7: 265-68.
9. Song X, Qian Y (2013): IL-17 family cytokines mediated signalling in the pathogenesis of inflammatory diseases. Cell Signal., 25: 2335-2347.

10. Nasreldin E, Safwat D, Hamed $H$ et al. (2016): Tregulatory and T-helper type 17 Cells Associated Cytokines (IL-35, IL-17) as Potential Diagnostic and Prognostic Biomarkers in Egyptian Acute Myeloid Leukemia Patients. J Clin Cell Immunol., 7: 478.

11. Mahfouz K, Abo-Nar A, Bendary S (2018): Role of Interleukin17F (IL17F) Gene Polymorphism in Susceptibility to Acute Myeloid Leukemia. J Leuk., 7: 25256.

12. Abousamra N, El-Din M, Helal R (2013): Prognostic value of Th17 cells in acute leukaemia. Med Oncol., 30 (4): 732.

13. Wrobel T, Gebura K, Wysoczańska B et al. (2014): IL$17 \mathrm{~F}$ gene polymorphism is associated with susceptibility to acute myeloid leukaemia. J Cancer Res Clin Oncol., 140 (9): 1551- 1555.

14. Elsissy M, Abdelhafez A, Elmasry $M$ et al. (2019): Interleukin-17 Gene Polymorphism Is Protective Against the Susceptibility to Adult Acute Myeloid Leukaemia in Egypt: A Case-Control Study. Open Access Maced J Med Sci., 7 (9): 1425-1429.

15. Zhu B, Zhang J, Wang $X$ et al. (2015): Correlation between acute myeloid leukaemia and IL-17A, IL-17F, and IL-23R gene polymorphism. International Journal of Clinical and Experimental Pathology, 8 (5): 5739-5743.

16. Ersvaer E, Liseth $\mathrm{K}$, Skavland J et al. (2010): Intensive chemotherapy for acute myeloid leukaemia differentially affects circulating TC1, TH1, TH17 and TREG cells. BMC Immunology, 11: 38-42.

17. Rashed R, Shafik R, Shafik N et al. (2018): Associations of interleukin-10 gene polymorphisms with acute myeloid leukaemia in human (Egypt). J Can Res Ther., 14: 1083-8. 